\title{
ANALYSIS OF APPROACHES TO THE FORMATION OF PROFESSIONAL READINESS OF STUDENTS IN UZBEKISTAN (ON THE EXAMPLE OF FUTURE TEACHERS)
}

\section{Khusan Abdurakhimovich Umarov}

Lecturer, Tashkent State Pedagogical University, Tashket, Uzbekistan.

E-mail: umarov.khusan@gmail.com

\section{ABSTRACT}

Studying the further development of higher education, improving the quality of education, expanding the integration of science and industry, we came to the following conclusions: literature on the formation of professional education of students, as well as an analysis of educational (and pedagogical) practice in higher education, despite the fact that more was done work on the development of professional readiness of students, the problem of the formation of professional readiness of future teachers has not yet been completely resolved. To solve this problem, we set ourselves the following tasks: to explain the concept of "professional readiness" among future teachers, taking into account the requirements of the time (for example, students of pedagogical universities); analyze factors affecting student readiness; development of innovative methods of forming students' readiness.

A practical study of the problem showed that the most effective process of forming the professional readiness of a future teacher occurs in a real process or in the process of educational activity close to it. Building on the educational process on the basis of an innovative approach, bachelors develop creative skills to analyze existing materials needed to solve professional problems, to independently solve new problems.

The study showed that the practical activity of students in their chosen specialties guarantees clear prospects for future professional growth, as well as employment, contributes to the formation and increase of their professional competence; The development of the experimental and educational base of educational institutions, increasing the level of education provided, stimulating the professional growth of teachers, the customer will be given the opportunity to train highly qualified personnel on the basis of educational institutions.

\section{Keywords:}

innovation, collaboration, formation readiness, integration processes, professional education, practical activities

Article Received: 18 October 2020, Revised: 3 November 2020, Accepted: 24 December 2020

\section{Introduction}

The active development of society in all spheres of professional activity has led to the emergence of a new factor in human labor activity - "the competitiveness of a specialist". The rapid increase in the volume and density of new knowledge, information flow, accelerates the process of spiritual "obsolescence" of theoretical knowledge obtained in higher education, which is the main stage in the formation of the factor of preparing students for professional activity.

That is why President Sh.M.Mirziyoyev spoke about the further development of higher education, improving the quality of education, expanding the integration of science and industry: "We need quality, not quantity. For this it is necessary to study the experience of foreign countries. Whichever country pays special attention to education they will win. Our most important task is to create a learning system based on scientific experience "[1].

The teacher remains the main and important person in these educational reforms. As said the famous teacher K.D.Ushinsky: "There is no way to improve anything in the field of education, in general, in the work of the school, by passing the head of the teacher." For this reason, it is unreasonable to expect results from reforms in the education system without preparing teachers who play an important role in educating the future youth of Uzbekistan for professional pedagogical activity. [2]

The literature on the problems of the formation of professional education of students, as 
well as the analysis of the organization of educational (and pedagogical) practice in higher education showed us that a number of works have been done to develop the professional education of students. However, it should be noted that the research data showed that one of the components of training is the ability to apply in practice the knowledge gained in the learning process.

The theoretical knowledge gained by students in the educational process will undoubtedly become the basis of their professional skills. But at the same time, not only the knowledge of future teachers is important, but also the level of professional readiness. Confirmation of this can also be seen in the results of a number of recent studies conducted by local and foreign scientists. The result of these studies showed that they studied various aspects of the preparation of future teachers, but still insufficiently studied formal, non-formal and informal forms of education, and especially their continuity, as well as their integration with practical activities [2].

\section{Materials and methods}

However, analyzing the work of local researchers (R.Kh. Dzhuraev [3], N.A. Muslimov [4], E.O. Turdikulov [5], Ya.A. Khamidov [6], Z.K. Ismailov [7] , U.K. Tolipov [8], D.O. Himmataliev [9] and others) and the CIS countries (O.L. Abdullina [10], L.V. Antropova [11], E.M. Borisova [12], I. A. Zimnyaya [13], N. V. Kuzmina [14], M. I. Lukyanova [15], S. N. Mironenko [16], T. M. Sorokina [17], O E. Permyakov, S. V. Menkova [18], V. A. Mezenin, L. N. Cheganova [19] and others), we came to the conclusion that despite their great interest and the importance of the results achieved, the problem formation of professional pedagogical education of future teachers still remains completely unresolved. The main reasons for this are:

The theoretical and pedagogical foundations of the process of forming the professional education of future teachers, which are reflected in the content, essence and possibilities of their development, have not been sufficiently developed;

- the predominance of traditional approaches, which are satisfied with the fact that students have a theoretical understanding of the process, and not the formation of practical training of future teachers;

- $\quad$ instead of a systematic approach to organizing the process, an approach is used that consists of random, unrelated, random components;

- Reasons such as the discrepancy between the levels of development of assessment technology and assessment of the results of the formation of professional education of future students that meet modern requirements for high-quality assessment in education, imply research on the issues of professional pedagogical education of future teachers.

This problem requires researchers to analyze the work of scientists from developed countries of the West and East, to improve the existing methods of forming the professional education of future teachers - to replace it with innovative methods that meet modern requirements.

To achieve this goal, we have set ourselves the following tasks:

1. Explain the concept of "professional education" of future teachers, taking into account modern requirements (on the example of students of pedagogical universities);

2. Analysis of the factors influencing the preparation of students;

3. Development of innovative methods of students' readiness formation.

First of all, let us analyze the concept of professional education, which is the object of research.

Today, the concept of preparedness as a whole is viewed by researchers from different points of view. "Readiness" means a certain level of personal development, a temporary situation, attitude, a mechanism for regulating activity, a particular long-term or short-term state of mind 
and the concentration of personal forces focused on certain actions. Readiness can be interpreted at the level of value orientations, that is, quality and status, and a dynamic process [20]

Professional education is a system of organizational and pedagogical measures that ensure the formation of professionally oriented knowledge, skills and abilities in a person and provide professional education for such activities in pedagogical higher education - universities, institutes. An important component of professional pedagogy is teaching practice. [21, p.230]

Professional training is a system of professional education aimed at accelerating the acquisition by students of the skills necessary to perform a specific job, a group of jobs. Professional training is not carried out by raising the level (stage) of education of students. If necessary, the state provides access to professional training for persons who do not have basic general education. Professional education can be obtained in primary professional education institutions and other educational institutions: in interschool educational complexes, educational industrial complexes and educational workshops, as well as in educational departments of licensed organizations, and on the basis of individual training of licensed and certified specialists. [22]

As Aristotle said, "The mind consists not only in knowledge, but also in the ability to apply knowledge in practice." Despite the fact that this idea appeared a long time ago, it has recently been actively used in modern pedagogy. That is, the development of pedagogical education initially went in the direction of the technologization of education. The teachers focused on the introduction of pedagogical technology to improve the quality of education. Recently, the modernization of training has gone in the direction of introducing innovations, focusing on the intractability of learning and the formation of competence is the main indicator of the learning outcome and not knowledge

Until recently, the level of training of a graduate was considered as the presence of certain knowledge, abilities and skills, and in new conditions this view is understood as the formation of certain general and professional competencies in students. Thus, the professional and pedagogical education of a student is considered as a complete systemic process only when the ability to form a holistic algorithm for performing an atypical task is realized using the elements of knowledge and skills acquired to date to solve typical problems of pedagogical activity. From this we can conclude that readiness is the ability to form elements of knowledge and skills acquired at the moment for solving typical tasks in the form of a holistic algorithm for performing an atypical task.

\section{Result and discussion}

The presence of competence is assessed by the results of human labor. The level of competence of a specialist in each area is determined by the degree of compliance of his work with the requirements for the final result of this professional activity.

We defined the teacher's competence as a factor of his readiness, his readiness and ability for professional activity, adding to the authors' opinion that the professional competence of teachers is a specific feature of their training - a unit of theoretical and practical readiness. This interpretation allows us to interpret the concepts of "professional readiness" and "professional competence" as synonyms.

For the formation of professional education of students, it is advisable to highlight the factors that have the greatest influence on this process. Knowledge of the factors influencing the formation of professional education will help determine the most effective ways and means of forming the professional education of future teachers.

A practical study of the issue has shown that the most effective process of forming the professional readiness of a future teacher takes place in a real process or in the process of educational activity close to it. Building the educational process on the basis of an innovative 
approach, bachelors develop creative skills in analyzing the available materials necessary for solving professional problems, regardless of them, taking on new problems.

In philosophical research, special attention is paid to practical activities. Practicing, a person enriches his worldview and, accordingly, expands his needs and assimilates new layers of life.

But in most of them the main emphasis was not on the implementation of the real process, but on the formation of the volume and content of academic disciplines, the level of thorough assimilation of educational materials by students. As a result, the problem of adequate provision of universities with the needs of potential employers and their interaction with other partner organizations in the labor market is not fully resolved.

Scientific works which we researched, on the topic of the relationships between educational institutions with partner organizations is mainly focused on the study of the processes of their cooperation and integration. In their opinion, integration processes in education in conjunction with industry and science help educational institutions to form a single educational space. This, in turn, ensures such achievements as the transfer of concepts, ideas, principles, knowledge, methods and technologies, resources and personnel from one area to another, their effective use, and the introduction of new forms of collaboration. Such integration processes help educational institutions to form a single educational space in cooperation with science and industry. In practice, the integration of industry, science and educational institutions allows each of these three areas to transfer and effectively use various resources from one area to another, such as general concepts, ideas, principles, knowledge, methods and technologies and human resources, creating new forms of collaboration.

However, in addition to listing the achievements of these integration processes, it is necessary to take into account their specific and complex aspects. The main difficulty of integration lies in the fact that the three systems that are currently sufficiently formed - the methods of work of science, education and industry, must change the mechanisms of work.

\section{Conclusion}

In our opinion, the main mistake of researchers studying the processes of cooperation or integration lies in their attempts to change the methods and principles of the three systems (industry, science and education) that have been formed over the years. We chose students as a moving mechanism - as a tool - as a simpler and easier solution to a problem. According to him, students make the most of their hours of independent study and work as volunteers, interns, practitioners, in order to find solutions to existing problems in this area and check their solutions on the spot, test themselves in professional activities, gain experience.

A questionnaire survey was conducted among high course students (3-4 courses) and university professors to confirm our theory based on a theoretical analysis of the literature. To the research was involved 126 students of 3-4 courses and 57 teachers of universities (TSPU, JSPI, NamSU in Uzbekistan). The respondents were asked to list sequentially the importance of the factors identified as a result of the analysis of psychological and pedagogical literature, which, in their opinion, have a significant impact on the formation of professional training of students. The collected data showed an unexpected result. What we considered important - (educational and pedagogical) internships, was underestimated by students and even some teachers and ranked last among the factors influencing the professional training of students.

To clarify the situation, another survey was organized, with questionnaires using openended questions and asking them to comment on facts that explained their views. Although the responses received have been interpreted in different ways, logical commonality has led to the following conclusions.

- insufficient effective organization of educational and pedagogical practice 
- reality sometimes differs slightly from the situations studied in theoretical classes in the classroom.

- educational and pedagogical practice is not aimed at solving a specific problem (or a set of problems), it is carried out as a whole (for the purpose of familiarization), etc.

One of the remarks that caught our attention was given by the students, according to which "Educational and especially pedagogical practice is planned for the end of the course. ... It is impossible to analyze it at the end of the operation, ... to correct the mistakes. "

Cooperation of science, education and industry all over the world is manifested in various forms, the most common methods in the developed countries of the West: technoparks; incubators of new technologies; innovation and technology centers; innovative industrial complexes organized with the participation of universities, licensing and certification, leasing and marketing centers; scientific and educational complexes; multistage models of information systems, taking into account the peculiarities of interaction between education, science and industry; corporate universities and others. The pinnacle of these processes is integration. According to UNESCO, the active development of corporate education is associated with the increasing role of intellectual capital in modern companies [23]

The research has shown that students' actions, focused on practical activities in the chosen specialties, guarantee clear prospects for future professional growth, as well as employment, contribute to the formation and improvement of their professional competence; development of the experimental and educational base of educational institutions, increasing the level of education provided, stimulating the professional growth of professors and teachers, the customer will be given the opportunity to train highly qualified personnel on the basis of educational institutions.

\section{References}

[1] Shavkat Mirziyoev: Bizga miqdor emas, sifat kerak [Shavkat Mirziyoyev: we need quality, not quantity] Available at: https://uza.uz/oz/politics/shavkatmirziyeev-ilm-fan-namoyandalari-bilanmulo-ot-ildi-24-05-2019

(acessed 30.06.2020)

[2] Kh.A.Umarov Incessancy of education and activities in the development of professional education The American journal of social science and education innovations Volume-II Issue-VII 2020, pp256-263

[3] Djuraev R.X. Organizatsionnopedagogicheskie osnovi intensifikatsii sistemi professionalnoy podgotovki $\mathrm{v}$ uchebnix zavedeniyax professionalnogo obrazovaniya [Organizational and pedagogical foundations of the intensification of the professional education system in educational institutions of professional education] Abstract of the dissertation doctor of pedagogical sciences, Tashkent 1995, 43 p.

[4] Muslimov N.A. Kasb ta'limi o'qituvchisini kasbiy shakllantirishning nazariy metodik asoslari [Theoretical and methodological bases of professional development of professional education teachers] Dissertation, doctor of pedagogical sciences, Tashkent 2007, 315 p.

[5] Turdiqulov E.O., Djuraev R.X. and others Integratsiyalashgan ta'lim nazariyasi va amaliyoti [Theory and practice of integrated education] manual, Publishing House "Sano-standart", Tashkent 2009. $176 \mathrm{p}$.

[6] Hamidov J.A. Bo'lajak kasb ta'limi o'qituvchilarini tayyorlashda o'qitishning zamonaviy didaktik vositalarini yaratish va qo'llash texnologiyasi [Technology for the development and application of modern teaching aids in the training of future 
teachers of professional education] Abstract of the dissertation doctor of pedagogical sciences, Tashkent 2017

[7] Ismailova Z.K. Talabalarning kasbiy pedagogik malakalarini shakllantirish [Formation of professional pedagogical skills of students] Dissertation, Doctor of Philosophy in Pedagogy, Tashkent 2000. $186 \mathrm{p}$.

[8] Tolipov U.K. Oliy pedagogik ta'lim tizimida umummehnat va kasbiy ko'nikma va malakalarni rivojlantirishning pedagogik texnologiyalari [Pedagogical technologies for the development of general and professional skills in the system of higher pedagogical education] Dissertation, doctor of pedagogical sciences, Tashkent 2004, 314 p.

[9] Ximmataliev D.O. Integration of pedagogical and technical knowledge in the diagnosis of professional education (on the example of "professional education" in higher education). Dissertation, doctor of pedagogical sciences, Tashkent 2018, 230 p.

[10] Abdullina O.L. Obshepedagogicheskaya podgotovka uchitelya $\mathrm{v}$ sisteme visshego pedagogicheskogo obrazovaniya [General pedagogical education of teachers in the system of higher pedagogical education: for ped. specialties of higher educational institutions] manual for pedagogical specialties of higher educational institutions. - 2nd pub. Moskow 1990, Publishing House "Prosveshenie", 141 p.

[11] Antropova L.V. Formirovanie professionalnoy gotovnosti uchitelya $\mathrm{k}$ pedagogicheskoy deyatelnosti v adaptivnoy shkole [Formation of the teacher's professional readiness for pedagogical activity in an adaptive school] Dissertation, doctor of pedagogical sciences, Moskow 2004, 396 p.

[12] Borisova E.M. Professionalnoe samoopredelenie: lichnostnoy aspekt.: [Professional self-determination: personal aspect] Abstract of the dissertation doctor of psychological sciences, Moskow 1995, $41 \mathrm{p}$.

[13] Zimnyaya I.A. Klyuchevie kompetensii novaya paradigma rezultata obrazovaniya [Key competencies - a new paradigm of educational outcomes] journal Visshee obrazovanie segodnya [Higher education today] № 5 2003, pp. 34-42.;

[14] Kuzmina N.V. Professionalizm lichnosti prepodavatelya i mastera proizvodstvennogo obucheniya [Professionalism of the personality of the teacher and master of industrial education] Moskow manual Publishing House "Visshaya shkola" 1990, 117 p.

[15] Luk'yanova M.I. Psixologopedagogicheskaya kompetentnost uchitelya [Psychological and pedagogical competence of a teacher] journal Pedagogika № 10 2001, pp. 56-61 (in Russian)

[16] Mironenko S.N. Integratsiya pedagogicheskogo i texnicheskogo znaniya kak uslovie podgotovki pedagoga professionalnogo obucheniya $\mathrm{k}$ diagnosticheskoy deyateltnosti [Integration of pedagogical and technical knowledge as a condition for training a teacher of professional education for diagnostic activities] Dissertation for the degree of candidate of pedagogical sciences Cherepoves 2014, 164 p.

[17] Sorokina T.M. Razvitie professionalnoy kompetensii budushego uchitelya sredstvami integrirovannogo uchebnogo soderjaniya [Development of the professional competence of the future teacher by means of integrated educational content], Journal Nachalnaya shkola №2 2004, pp. 110 - 114 (In Russian)

[18] Permyakov O.E., Menkova S.V. Diagnostika formirovaniya professionalnix kompetensiy [Diagnostics of the formation of professional competencies] monography Moskow 2010 (In Russian) 
[19] Mezenin V.A., Cheganova L.N. Sotsialnoe partnerstvo kak perspektiva integratsionnix protsessov $\mathrm{v}$ sfere professionalnogo obrazovaniya [Social partnership as a prospect of integration processes in the field of professional education] Materiali I Mejdunarodnoy nauchno-prakticheskoy konferensii [Materials of the I International Scientific and Practical Conference] Ekaterinburg, 25-26 january 2011, pp 116-118 (In Russian)

[20] Osnovi pedagogicheskogo masterstva [Fundamentals of pedagogical excellence] Available at: https://studfile.net/preview/1845143/page: 7/ (acessed 30.06.2020)

[21] E.G.Azimov A.N.Shukin Noviy slovar metodicheskix terminov i ponyatiy (teoriya i praktika obucheniya yazikam) [New dictionary of methodological terms and conceptsv (theory and practice of language teaching)] Moskow 2009448 p

[22] B.M.Bim-Bad Pedagogicheskiy ensiklopedicheskiy slovar. [Pedagogical Encyclopedic Dictionary] - M., 2002. 223.

[23] 23. Itogi i perspektivi integrirovannoy sistemi obrazovaniya $\mathrm{v}$ visshey shkole Rossii: obrazovanie - nauka innovatsionnaya deyatelnost Available at: https://books.google.co.uz/books?id=rwgb 3NHHsBEC (acessed 30.06.2020) 